\title{
Thermal Diagnosis of Heat Conduction and Combustion Time of Fruits of the Brazil Nut Tree (Bertholletia excelsa Bonpl.)
}

\author{
Adenes Teixeira Alves ${ }^{1 *}$, Lucieta Guerreiro Martorano², Gelson Dias Florentino ${ }^{3}$, \\ Dimas José Lasmar ${ }^{1}$, Íres Paula de Andrade Miranda ${ }^{4}$, Leila Sheila Lisboa ${ }^{5}$, Jamal da Silva Chaar ${ }^{1}$ \\ ${ }^{1}$ Federal University of Amazonas-UFAM, Manaus, Amazonas, Brazil \\ ${ }^{2}$ Brazilian Agricultural Research Corporation (EMBRAPA) Eastern Amazon (CPATU/NAPT), Santarém, Pará, Brazil \\ ${ }^{3}$ Biodiversity and Biotechnology Network of the Legal Amazon (Bionorte), Belém, Pará, Brazil \\ ${ }^{4}$ National Institute for Amazon Research (INPA), Manaus, Amazonas, Brazil \\ ${ }^{5}$ Geoprocessing, Belém, Pará, Brazil \\ Email: * professoradenes@hotmail.com, martorano.lucietta@gmail.com, gelson.florentino@lasalle.org.br, \\ dimas.lasmar@gmail.com, ires@inpa.gov.br, leilasheila@gmail.com, jchaar@gmail.com
}

How to cite this paper: Alves, A.T., Martorano, L.G., Florentino, G.D., Lasmar, D.J., de Andrade Miranda, Í.P., Lisboa, L.S. and da Silva Chaar, J. (2020) Thermal Diagnosis of Heat Conduction and Combustion Time of Fruits of the Brazil Nut Tree (Bertholletia excelsa Bonpl.). Advances in Bioscience and Biotechnology, 11, 60-71.

https://doi.org/10.4236/abb.2020.112005

Received: December 27, 2019

Accepted: February 22, 2020

Published: February 25, 2020

Copyright $\odot 2020$ by author(s) and Scientific Research Publishing Inc. This work is licensed under the Creative Commons Attribution International License (CC BY 4.0).

http://creativecommons.org/licenses/by/4.0/

\begin{abstract}
The objective of this work was to evaluate the spatial and temporal dynamics of the process of combustion of fruits of the Brazil nut tree (Bertholletia excelsa Bonpl.) using thermographic images in order to characterize the potential of this biomass as an energy source for use in ceramic kilns. Infrared thermography was used as a diagnostic tool, and the trial was conducted in November 2018, in two blocks with two repetitions in each, with the fruits organized so that the cavity was oriented upward and also downward. The thermograms were analyzed using Flir Tools $(6.3 \mathrm{v})$. The temperatures were the highest in the center of the fruits $\left(>160^{\circ} \mathrm{C}\right)$, attaining incandescence in $6 \mathrm{~min} 30$ s. Heat was propagated from the center to the edge, and this process was quicker for fruits with their cavities pointed upward. A second order polynomial model explained combustion time with a maximum duration of 7.2 minutes. The thermographic diagnostic has the potential to be used in management strategies for this biomass as an energy source, thus aggregating value to the residuals that are normally left in the forest during harvest by extractivists.
\end{abstract}

\section{Keywords}

Residual Biomass, Thermographic Patterns, Non-Wood Forest Products

\section{Introduction}

The biodiversity of the Amazon rain forest possesses great biotechnological and 
bioenergetic potential through byproducts and substances from extraction processes, and these are capable of generating expressive economic benefits for the population in the region [1]-[20]. Among these possibilities are native species such as the Brazil nut tree (Bertholettia excelsa Bonpl. Lecythidaceae) which has great potential to aggregate value through non-wood forest products [2], its fruits are denominated ouriços, and have an average weight of $1.6 \mathrm{~kg}$, contain 12 to 25 seeds, are covered by a very thick and resistant bark, wherein the seed in natura is found [17].

The Brazil nut has been gaining in economic importance, principally due to the results from research on its nutritional value [16] [17] [18]. In some places in the Amazon the Brazil nut is the principal extractivist product that is exported, and it also has high potential for energy generation from residual biomass from its harvest [4]. Since it is very abundant in the region, the Brazil nut tree can also be considered a key species for the evaluation of indicators of conservation and development, since its harvest occurs in native forests each year. The harvest of the Brazil nut itself has low environmental impact [21] but the pericarp of the fruit, after having the seeds removed, is rarely used.

Brazilian production of B. excelsa in the period between 2012 and 2013 was 38,805 and 38,300 tons, respectively, and concentrated in the North region, which produced in 201336,704 tons, totaling $96 \%$ of national production, with the greatest production in the states of Acre, Amazonas and Pará. Furthermore, production is greater during the rainy season, and years with greater rainfall cause an increase in the harvest of the following year [19].

Currently, there is an intense demand for Brazil nuts in local, regional, national and world markets, which increases job availability, income, and interest of businesses, and producers to install companies in Brazil nut producing regions. Furthermore, the Brazil nut trade strengthens production chains that are the base of agroextrativist communities [5].

The combustion of biomass is a conversion technology based on the principle of transformation of chemical energy into thermal energy through a series of chemical reactions [7]-[15]. The use of technologies capable of diagnosing the heating process and the response time can help in understanding the process of conversion of energy stored in the biomass (fruit of the Brazil nut) up to the point of combustion. Biomass combustion is mainly used for heat production in small and medium scale units such as wood stoves, log wood boilers, pellet burners, automatic wood chip furnaces, and straw-fired furnaces [18]. The thermal gradient expressed as a gradient of colors indicates that the radiation in the infrared spectrum is proportional to the temperature of what is being measured [9]. It is important to emphasize that thermography allows for the identification of thermal responses from the energy emitted by the surface of the measured object and the transformation of this response into an image showing thermal gradients as captured by a thermographic camera [22].

In light of the extensive variety of technological resources and tools currently available, the objective of this work was to evaluate the spatial and temporal dy- 
namics of the process of combustion of fruits of the Brazil nut tree (Bertholletia excelsa Bonpl.) using thermographic images in order to characterize the potential of this biomass as an energy source for use in ceramic kilns in the Amazon.

\section{Material and Methods}

The samples of Brazil nut fruits (Bertholletia excelsa Bonpl.) were collected at the beginning of the month of November, 2018, at Fazenda Aruanã $\left(03^{\circ} 00^{\prime} 30.63^{\prime \prime}\right.$ S and $\left.58^{\circ} 45^{\prime} 50^{\prime \prime} \mathrm{W}\right)$, altitude $150 \mathrm{~m}$, located on the AM-010 highway, municipality of Itacoatiara, Amazonas, Brazil (Figure 1).

The material selected for the experiment was transported to the city of Manuas where it was submitted to a drying process to remove excess humidity. After drying, the samples with diameter varying between 10 to $15 \mathrm{~cm}$ were transported to a ceramic kiln in nearby Iranduba $\left(03^{\circ} 08^{\prime} 19.8^{\prime \prime} \mathrm{S}\right.$ and $\left.60^{\circ} 21^{\prime} 39.3^{\prime \prime} \mathrm{W}\right)$, in order to conduct tests in kiln ovens at temperatures above $700^{\circ} \mathrm{C}$. These tests were conducted in order to quantify the time period that the fruits took to enter into combustion, and the entire process was monitored with an infrared thermographic camera, as shown in the image below.

The fruits were organized in two blocks, with one block having the fruit opening pointing upward and the other block with the opening facing downward. The fruits were placed in the oven, measuring the time needed for installation of the blocks in the front of the oven up to the initiation of combustion of a fruit. Subsequently, the samples were removed in order to conduct thermal imaging, which was also done on the external part of the oven with the objective of describing the process of heat conduction in the fruits.

The ovens are semi-continuous and of the type "paulistinha" (Figure 2(a) and Figure 2(b)). As a reference, the average temperature at the entry door of the oven was used, as this is the locale where materials to be burned are introduced for the process of brick burning (Figure 2(c) and Figure 2(d)).

In order to provide broader support to the experimental trials, georeferenced climate data for the area were used from [14] using only data from the state of Amazonas to spatially identify the region of Iranduba. Figure 3 shows that the Köppen climate type is $\mathrm{Am}_{3}$, indicating that during the least rainy month average rainfall is below $60 \mathrm{~mm}$, and annual rainfall is between 2000 and $2500 \mathrm{~mm}$. In this way, it is evident that the ceramic industry center of Iranduba has climate conditions that are propitious for growth of native Brazil nut stands in the Amazon.

As Iranduba is near the metropolitan area of Manaus, climatological data provided by the National Meteorological Institute (INMET) were also used, and based on a historical series from 1961 to 1990 it was determined that the study area has a thermal regime with an annual average temperature of $26.7^{\circ} \mathrm{C}$, maximum of $31.4^{\circ} \mathrm{C}$ and a minimum of $23.3^{\circ} \mathrm{C}$. With respect to the hydrological regime, annual average rainfall is $2307.4 \mathrm{~mm}$, with the rainiest month of March having $335.4 \mathrm{~mm}$ e, and August, the least rainy month, with $47.3 \mathrm{~mm}$, and average annual air relative humidity of $83.1 \%$ [6]. 


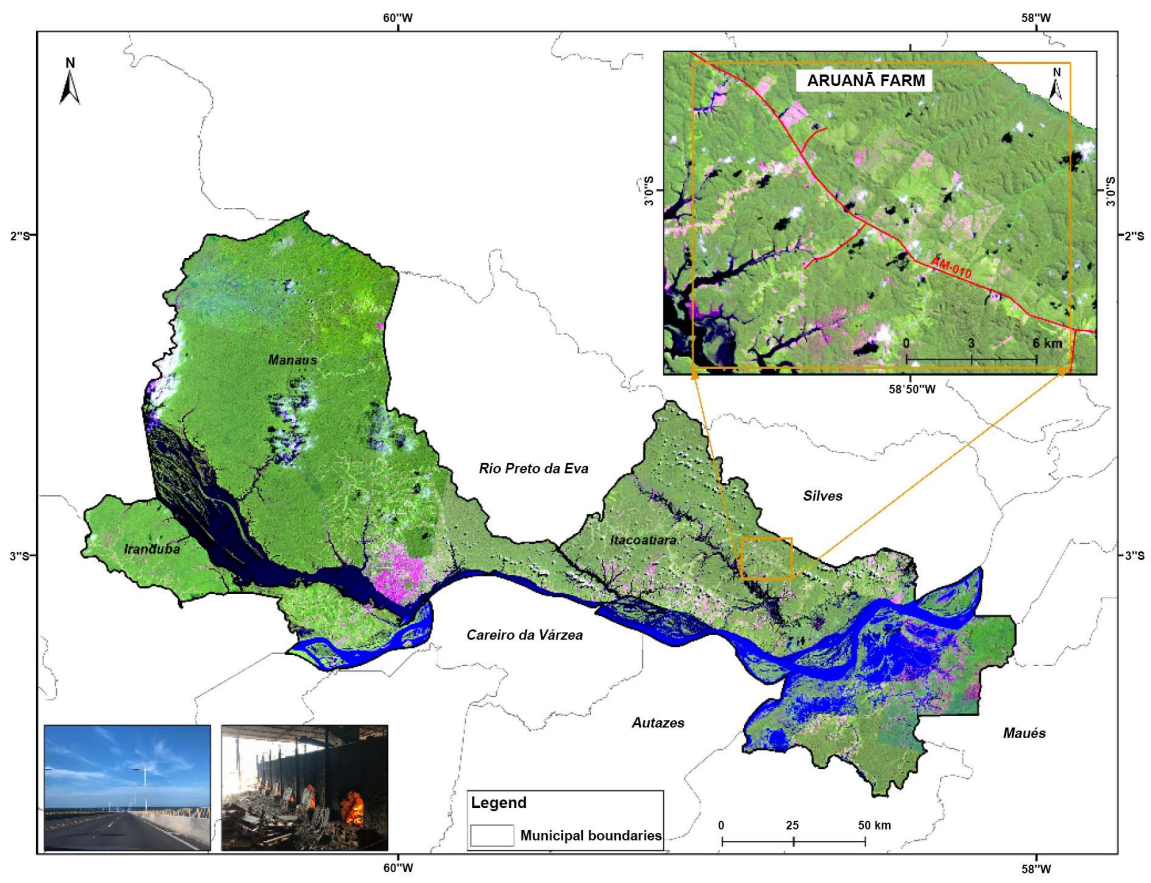

Figure 1. Image of location of Fazenda Aruanã situated on the east side of highway AM-10 (Manaus-Itacoatiara, km 215). Source: Authors.

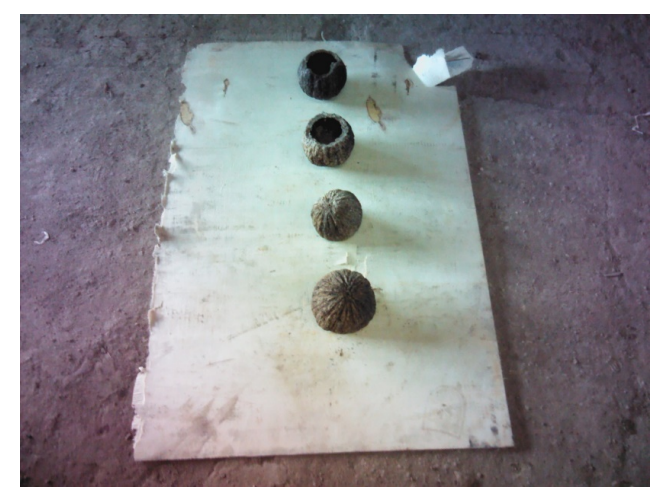

Figure 2. Chestnut hedgehogs from Brazil.

Climate data were also used from the automatic weather station of INMET at Manaus (latitude $03^{\circ} 06^{\prime} 19^{\prime \prime} \mathrm{S}$ and longitude $60^{\circ} 00^{\prime} 49^{\prime \prime} \mathrm{W}$ ) to identify climate conditions on the day the experiment was conducted (11/23/2018), which occurred between $15 \mathrm{~h}: 00 \mathrm{~min}$ and $16 \mathrm{~h}: 00 \mathrm{~min}$, taking into consideration that the experimental site was under the influence of climate conditions that were prevalent within the range of measurement of the automatic weather station at Manaus.

Data collection was conducted through image capture using a thermographic infrared camera (FLIR T650sc), with a $25 \mathrm{~mm}$ fixed lens, and a temperature scale of $40^{\circ} \mathrm{C}$ to $150^{\circ} \mathrm{C}$, and a thermal sensibility of $50 \mathrm{mK}\left(<0.05^{\circ} \mathrm{C}\right.$ at an ambient temperature of $30^{\circ} \mathrm{C}$ ). The camera's spectral scale ranged from 0.7 to $100 \mu \mathrm{m}$, but the image targets presented a response between 0.7 and $3.0 \mu \mathrm{m}$ and an optical resolution of $640 \times 480$ pixels with a maximum emissivity index of 0.95 . 


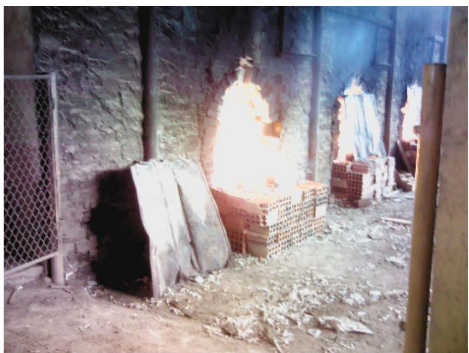

(a)

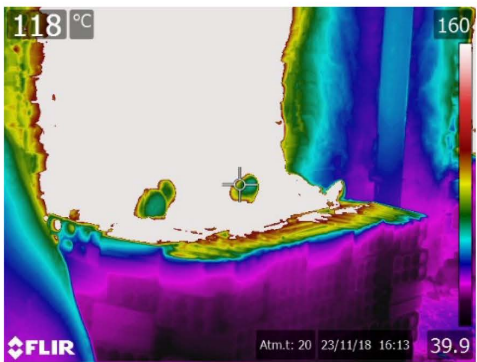

(c)

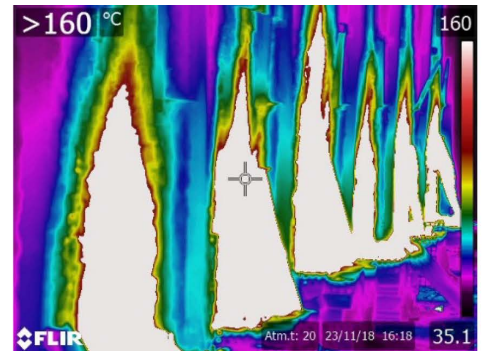

(b)

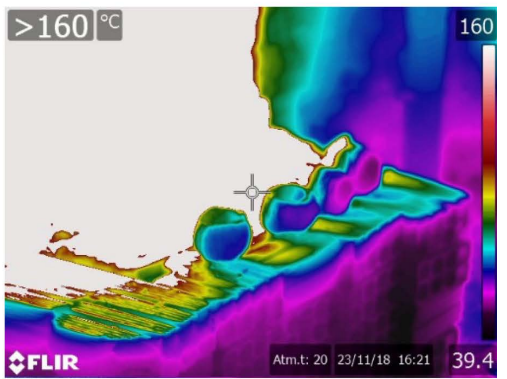

(d)

Figure 3. Brick kiln ovens at the ceramic industry center of Iranduba ((a) and (b)) and an example of the organization of the testing surfaces (fruits (c) and (d)).

Subsequently, the images were processed using the software Flir Tools, 6.3v [10], from which minimum, maximum, and amplitude thermal data were extracted.

The samples were distributed into four blocks, with two blocks having the fruit opening pointing upward and the other blocks with the opening facing downward, so that each block had at least one representative from each treatment group. For image treatment, the color palette was defined and categorized into thermal bands of white, red, yellow, green and blue. For evaluation of the thermal bands, five points were extracted from each image corresponding to each block, as shown in Figure 4.

The pattern of the thermal responses among the targets were statistically analyzed using the program BioEstat, version 5.3 [3], using Analysis of Variance (ANOVA). Furthermore, the functional relationship between the time necessary for the fruits to enter into combustion (the dependent variable (x)), and the thermal bands as the independent variable (y) was analyzed in order to verify whether the model can explain the process of heat conduction.

\section{Results and Discussion}

The meteorological variables at the moment of the experimental trials of imaging the targets at the ceramic kiln showed that average air temperature was $24.8^{\circ} \mathrm{C}$ and air relative humidity was $89.3 \%$, and there was no rainfall during the experiment. The thermographic pattern of the fruits showed that the temperature represented by white was above $160^{\circ} \mathrm{C}$, for both treatments of fruits with openings pointed upward and downward. For the red pattern the maximum, 


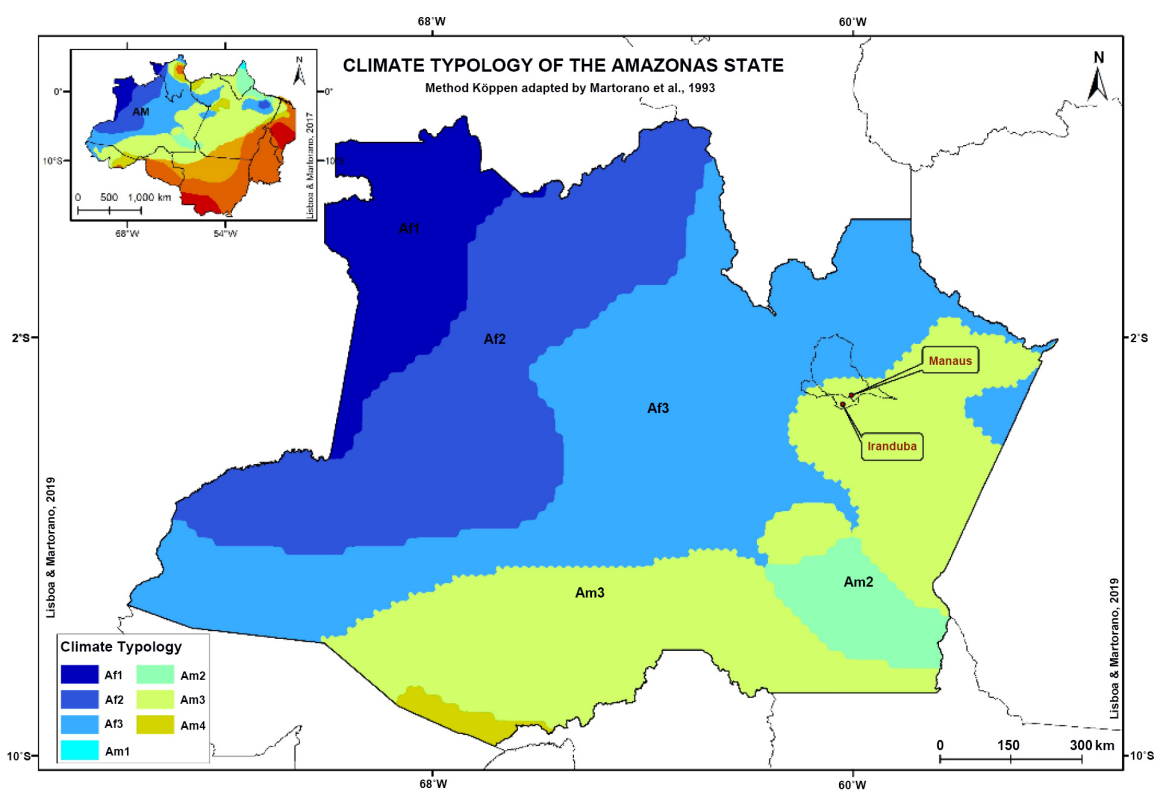

Figure 4. Köppen climate typology of the Legal Amazon adapted by Martorano et al. (1993), geodatabase used by Martorano et al. (2017).

minimum, and average temperatures were $135.3^{\circ} \mathrm{C}, 122.0^{\circ} \mathrm{C}$ and $128.5^{\circ} \mathrm{C}$, respectively. For the white and red patterns the fruits presented temperatures above $100^{\circ} \mathrm{C}$, indicating a greater concentration of heat in the center of the fruits. The samples extracted in the yellow pattern presented maximum values of $91.8^{\circ} \mathrm{C}$, a minimum of $84.8^{\circ} \mathrm{C}$ and an average of $86.9^{\circ} \mathrm{C}$.

In the areas represented by a green pattern the maximum thermal value was $75.0^{\circ} \mathrm{C}$, the minimum was $63.0^{\circ} \mathrm{C}$ and the average was $67.0^{\circ} \mathrm{C}$. The hottest areas of the blue pattern were $45.0^{\circ} \mathrm{C}$, with a minimum of $41.0^{\circ} \mathrm{C}$, for an average of $44.0^{\circ} \mathrm{C}$. The isotherms that expressed heat conduction demonstrated that in the center of the fruits the high temperatures surpassed the thermal limit of the thermographic camera, and that there was differentiation in the imaged surfaces, which was shown by the coincidence of the isotherms. The higher thermal amplitudes attained values around $13^{\circ} \mathrm{C}$, demonstrating that the fruits have high potential for heat conduction, because the values surpassed $120^{\circ} \mathrm{C}$. In areas on the periphery of the fruits the temperatures were above $40^{\circ} \mathrm{C}$, thus showing that the temperatures on the edges of the fruits were also very high (Figure 5).

Temperature elevation intensified during the interval between 3 to 5 minutes for both treatments of fruits with the openings upward and downward, and these initiated combustion after $5 \mathrm{~min}$ and $40 \mathrm{~s}$ and became completely incandescent when the material remained for $6 \mathrm{~min}$ and $30 \mathrm{~s}$ (Figure 6). The quickness of the combustion process of the fruits could be associated with their chemical composition which possess high lignin and cellulose contents [8] [9] [10] [11]. It is important to emphasize that for the block in which the fruits were with their openings pointed upward incandescence was more quickly reached.

The small variation between the block with their openings pointed downward could be related to a larger concentration of water vapor due to the difficulty of 


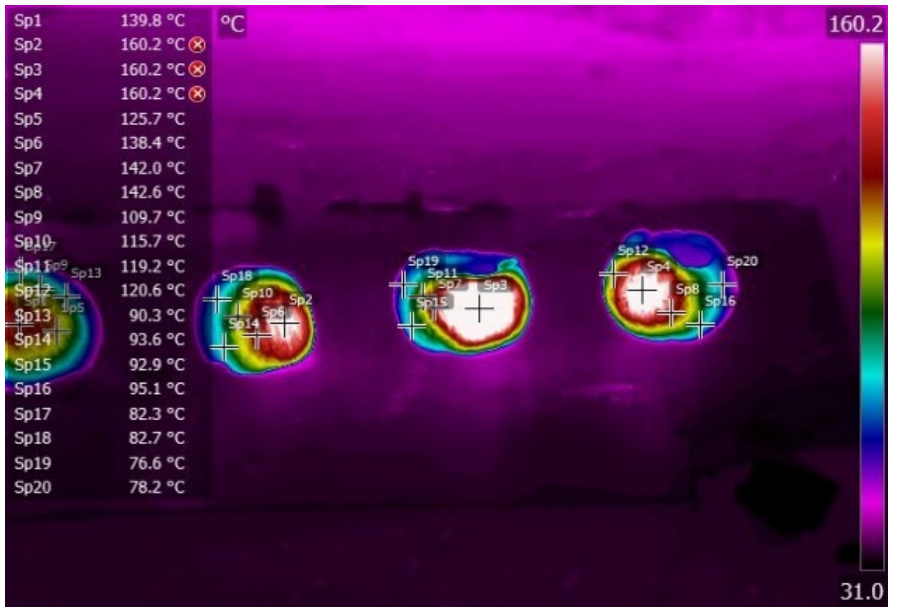

Figure 5. Example of an image indicating the targeted collection points on the fruits using Flir Tools.
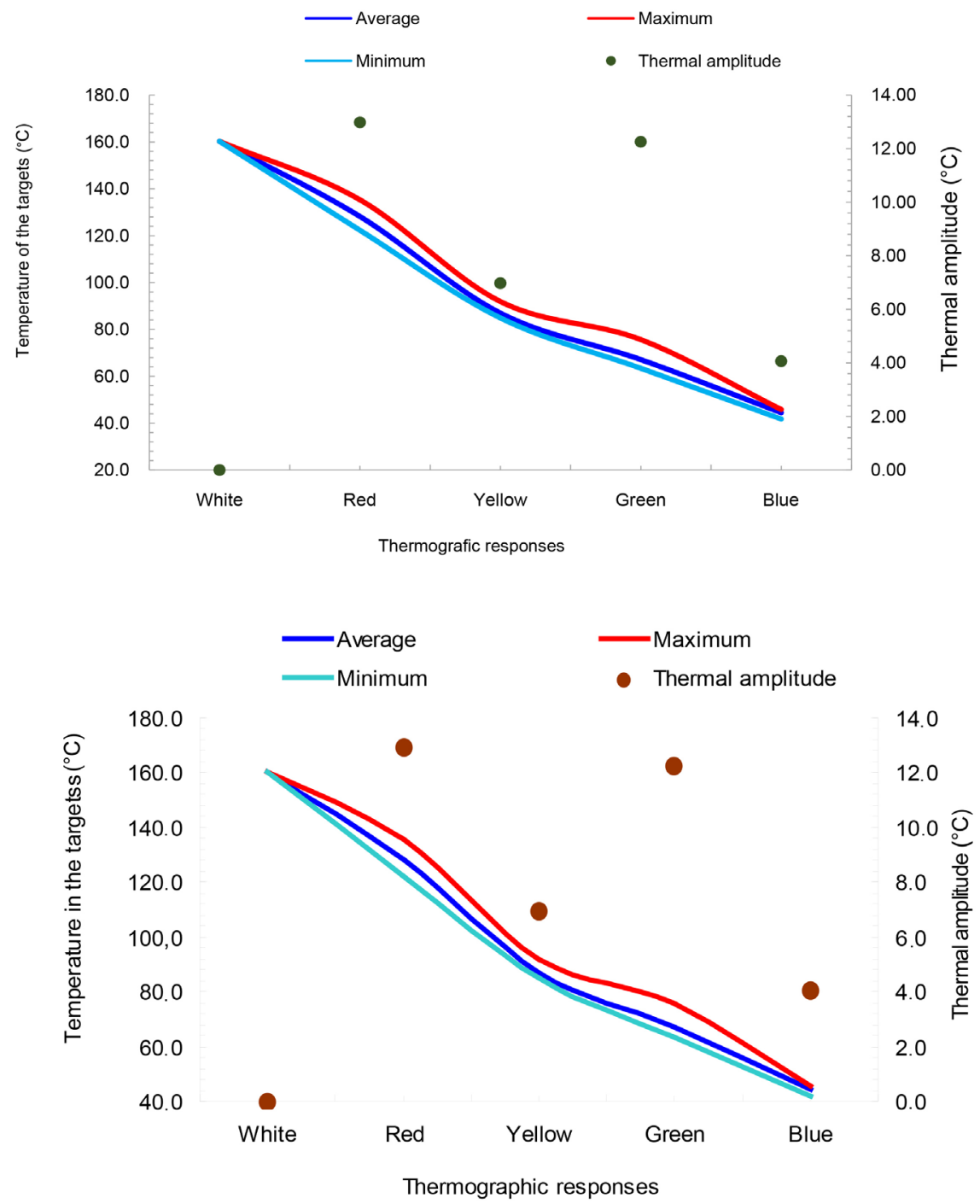

Figure 6. Thermographic diagnosis of heat conduction in fruits of the Brazil nut tree (Bertholletia excelsa Bonpl.). 
liberation of surrounding air in the process of heating the fruits. At $t_{1}(1 \mathrm{~min} 30$ s) the fruits reached an average temperature of $73.6^{\circ} \mathrm{C}$ with a rapid heating, and at $\mathrm{t}_{2}(3 \mathrm{~min} 00 \mathrm{~s})$ they reached average values of $118.0^{\circ} \mathrm{C}$. At $\mathrm{t}_{3}(4 \mathrm{~min} 00 \mathrm{~s})$ the temperatures had an average of $120.0^{\circ} \mathrm{C}$ which rapidly at $\mathrm{t}_{4}(5 \mathrm{~min} 00 \mathrm{~s})$ had an average of $133.0^{\circ} \mathrm{C}$. At $\mathrm{t}_{6}(7 \mathrm{~min} 00 \mathrm{~s})$ the fruits attained temperatures above $160.0^{\circ} \mathrm{C}$ and entered into combustion (Figure 5(a) and Figure 5(b)). There was a $97 \%$ probability that the temperatures of the fruits could be estimated by a second order polynomial, wherein he inflection point obtained by the first derivative occurs at 7.2 minutes, with this representing the maximum incandescence time of the fruit (Figure 7).

It was also observed that the block of fruits that had the fruit openings upward went through a more rapid cooling process than the block that had the fruit openings downward. After 5 min 00 of removal from the oven, the average temperature of the fruits that had their openings downward was reduced to nearly $65.0^{\circ} \mathrm{C}$, while that of the block that had the fruit openings upward was $62.0^{\circ} \mathrm{C}$. This difference of $3.0^{\circ} \mathrm{C}$ represents a point where a decision should be made during the process of organization of this biomass for placement in the ovens in order to guarantee a consistent supply of energy to the ovens and to further aggregate value to this material which is normally discarded in the forest by the harvesters. It is important to emphasize that this experiment with infrared thermography was conducted in order to aid with subsequent tests that will be conducted in order to quantify the number of fruits necessary to guarantee uninterrupted functioning of the industrial ceramic plant in Iranduba.

The areas of natural occurrence of Bertholletia excelsa in the Amazon are concentrated in the states of Acre, Amazonas, Pará, Amapá, Rondônia, Roraima, Mato Grosso and Maranhão [23]. In the state of Amazonas the municipalities that are most important for Brazil nut production are Beruri, Humaitá and Lábrea [12], and this demonstrates the potential for biomass production for use in kiln ovens in the ceramic industry centers around the Manaus metropolitan
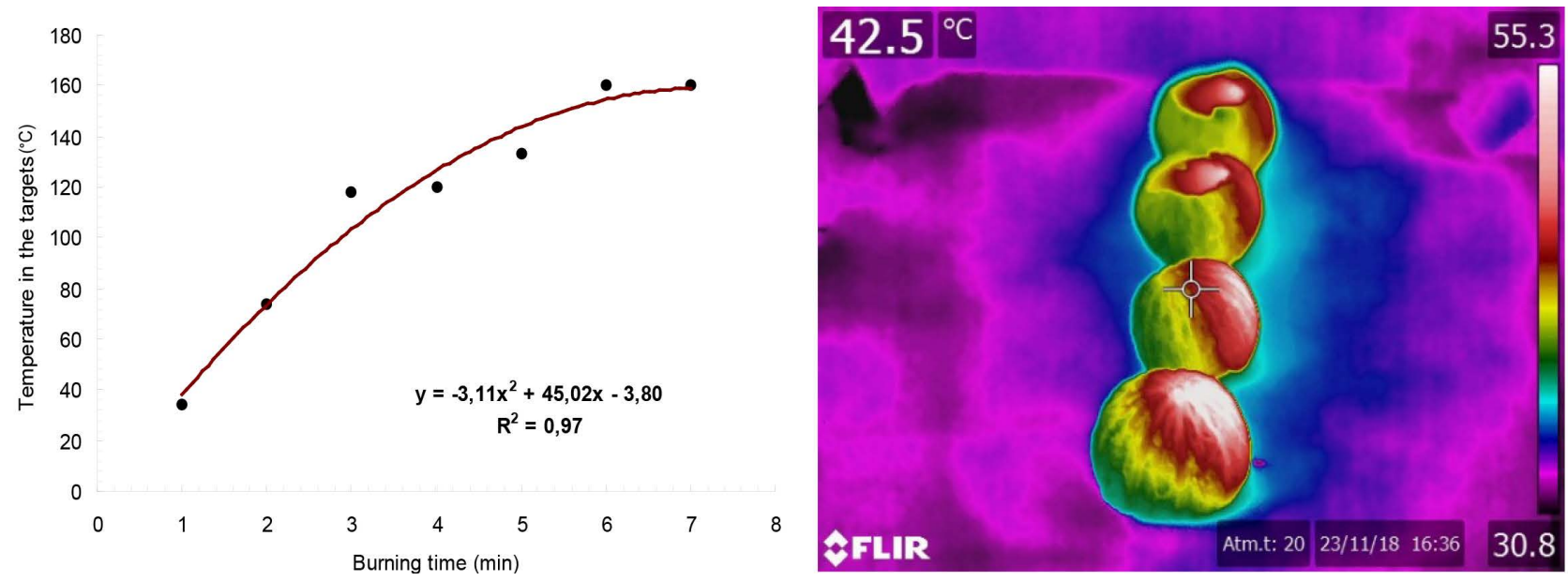

Figure 7. Second order polynomial model to estimate the average time of heat conduction in fruits of the Brazil nut tree (Bertholletia excelsa Bonpl.) as a strategy for use in kiln ovens in the ceramic industry center of Iranduba, Amazonas. 
region. Considering that a Brazil nut tree produces, on average, 236 fruits [13]-[24], and that each fruit possesses about on average 20 seeds [25], it is estimated that there is an annual production potential of 4720 seeds per tree. Also considering that the average weight of a seed is $6.0 \mathrm{~g}$ then the total weight of seeds produced per tree is $28.3 \mathrm{~kg}$ per harvest year. If average annual production is 40 thousand tons coming from 1,716,738 trees then potential biomass production would be 7 tons annually which could be used in the combustion process in the kiln ovens in the ceramic industry center of Iranduba near Manaus. Besides that, the Brazil nut can be considered a key species for combining conservation with development, as it is abundant in the Amazon region, harvested almost exclusively in natural forests, and due to the robust market demand, exploited by various communities in the short term and at low cost, in addition to the low environmental impact of the harvest [9]-[28].

The high lignin and cellulose content of the fruits cause them to begin combustion in 7 minutes, and this result indicates that the use of this biomass represents a strategy to provide an alternative fuel source for the ceramic kilns in the region, and further work and planning should be conducted to refine the estimates of the biomass volume needed on an annual basis.

\section{Conclusion}

Brazil nut fruits (Bertholletia excelsa Bonpl.) have a high potential for combustion, with a maximum time of 7.5 minutes. Using a second degree polynomial, combustion time was estimated for Brazil nut fruits as a strategy to aggregate value to this residual biomass that is normally discarded in harvests by agroextrativist communities. Thermal diagnosis allowed for quantification of the combustion time and identification of the bands of heat conduction in fruits, and these results can be used to aid in planning for the use of this residual biomass from non-wood forest products that is abundant in the Amazon. The advantage of using Brazil nut hedgehogs is very clear, as the combustion time is extremely fast compared to other Brazilian biomass. The biggest advantage of using chestnut hedgehogs as a fuel is to allocate an appropriate end without causing natural and environmental effects, in which they would be used for the production of coal, activated carbon, renewable fuels, among others, in addition to collaborating with the farming industry.

\section{Acknowledgements}

This research did not receive any specific grant from funding agencies in the public, commercial, or not-for-profit sectors. However, the authors thank EMBRAPA (MAPCAST Project), Rede BIONORTE and the Federal University of Amazonas (UFAM) for the scientific partnership in the doctoral research of the first and third authors, and the authors also thank the owner and collaborators of the Montemar Ceramic Company for their support during the field research. 


\section{Conflicts of Interest}

The authors declare no conflicts of interest regarding the publication of this paper.

\section{References}

[1] Astolfi, F.S., Nunes-Silva, C.G. and Bigi, M.F.M.A. (2014) Bioprospecção e biotecnologia. Parcerias Estratégicas, 19, 45-80.

http://seer.cgee.org.br/index.php/parcerias estrategicas/article/view/732

[2] Auca, E.C., Silva Dionisio, L.F., Bardales-Lozano, R.M. and Schwartz, G. (2018) Propagation of Brazil Nut (Humb. y Bonpl) Seedlings Using Seeds in Mini-Greenhouses. Revista Agro@mbiente On-Line, 12, 300-313. https://doi.org/10.18227/1982-8470ragro.v12i4.5222

[3] Ayres, M., Ayres, J.M., Ayres, D.L. and Santos, A.A.S. (2007) BioEstat: Aplicações estatísticas nas áreas das ciências biomédicas, Belém-Pará.

[4] Barbosa, M.A.M. and Moret, A.S. (2018) Ouriço da Castanha-do-Brasil. Diálogos Economia e Sociedade, 2, 45-54.

http://dialogos.saolucas.edu.br/index.php/REDIAL/article/view/13

[5] Bayma, M.M.A., Sá, C.P., Fonseca, F.L. and Wadt, L.H. (2014) Aspectos da cadeia produtiva da castanha-do-brasil no estado do Acre, Brasil. Boletim do Museu Paraense Emilio Goeldi. Ciências Naturais, 9, 417-426.

https://www.alice.cnptia.embrapa.br/handle/doc/996473

[6] BRASIL (1992) Departamento de Meteorologia. Normais climatológicas 1961-1990. Ministério da Agricultura e Reforma Agrária, Rio de Janeiro.

http://www.inmet.gov.br/portal/index.php?r=clima/normaisClimatologicas

[7] Cardoso, J.M. and João, J.J. (2019) Contextualization and Experimentation: An Interdisciplinary Approach of Chemistry and Physics Using Simulation Experiments of a Steam Engine. Revista Virtual de Química, 11, 339-352. https://doi.org/10.21577/1984-6835.20190024

[8] Carmona, I.N., Sampaio, J., Andrade, F.W.C., Júnior, C.D.C., Junior, S.M.O.M., Moreira, L.S. and Moutinho, V.H.P. (2017) Potencial energético da biomassa e carvão vegetal de resíduos de castanha-do-pará (bertholletia excelsa bonpl.). III Congresso Brasileiro de Ciência e Tecnologia da Madeira, Florianópolis. https://proceedings.science/cbctem/papers/potencial-energetico-da-biomassa-e-car vao-vegetal-de-residuos-de-castanha-do-para-\%28bertholletia-excelsa-bonpl.\%29

[9] das Graças Souza, A. and e josé Smiderle, O. (2019) Nutrição na Produção e Qualidade de Mudas da Porca do Brasil (Bertholletia excelsa HBK) No Norte Do Brasil. Revista Brasileira de Agropecuária Sustentável, 9.

[10] Eddy, A.L., Van, H.L.M. and Snyder, J.R. (2001) The Role of Thermographyin the Management of Equine Lameness. Veterinary of Journal, 162, 172-181. https://doi.org/10.1053/tvjl.2001.0618

[11] FLIR (2015) Manual da FLIR T650sc Systems 6.3v. Wilsonville.

[12] Freitas, J.B. and Naves, M.M.V. (2010) Composição química de nozes e sementes comestíveis e sua relação com a nutrição e saúde. Revista de Nutrição, 23, 269. https://doi.org/10.1590/S1415-52732010000200010

[13] IBGE, Instituto Brasileiro de Geografia e Estatística SIDRA (2013) Produção da extração vegetal e da silvicultura. Tabela 289: Quantidade produzida na extração vegetal, por tipo de produto extrativo. http://www.sidra.ibge.gov.br/bda 
[14] Ivanov, G.B. (2011) Influência de variáveis dendrométricas, anatômicas e ambientais na produção de frutos e sementes de Bertholletia excelsa H.B.K. 96f. Dissertação (Mestrado em Ciências Florestais), Universidade Federal de Santa Maria, Santa Maria.

https://repositorio.ufsm.br/bitstream/handle/1/8692/IVANOV\%2C\%20GUILHER ME\%20BOEIRA.pdf? sequence $=1$ \&isAllowed $=\mathrm{y}$

[15] Martorano, L.G., Vitorino, M.I., Caxias da Silva, B.P.P., Cabral de Moraes, J.R.S., Lisboa, L.S., Doff, S.E. and Reichardt, K. (2017) Climate Conditions in the Eastern Amazon: Rainfall Variability in Belem and Indicative of Soil Water Deficit. African Journal of Agricultural Research, 21, 1801-1810. https://doi.org/10.5897/AJAR2016.11801

[16] Moutinho, V.H.P., Rocha, J.J.M., Amaral, E.P., Santana, L.G.M. and Aguiar, O.J.R. (2016) Propriedades Químicas e Energéticas de Madeiras Amazônicas do Segundo Ciclo de Corte. FLORAM. Revista Floresta e Ambiente, 1, 1-7. https://doi.org/10.1590/2179-8087.131715

[17] Moodley, R., Kindness, A. and Jonnalagadda, S.B. (2007) Elemental Composition and Chemical Characteristics of Five Edible Nuts (Almond, Brazil, Pecan, Macadamia and Walnut) Consumed in Southern Africa. Journal of Environmental Science and Health, Part B, 42, 585-591. https://doi.org/10.1080/03601230701391591

[18] Nogueira, R.M., Silva, J.S., Alvares, V.S., Ruffato, S. and Lopes, R.P. (2014) Physical Properties of Brazil Nuts. Engenharia Agrícola, 34, 963-971. https://doi.org/10.1590/S0100-69162014000500015

[19] Nussbaumer, T. (2003) Combustion and Co-Combustion of Biomass: Fundamentals, Technologies, and Primary Measures for Emission Reduction. Energy \& Fuels, 17, 1510-1521. https://doi.org/10.1021/ef030031q http://148.72.150.188/you/documents/biomass\%20stoves/biomass\%20gasification $\%$ 204.pdf

[20] Santana, A.C., Santana, A.L. and Santana, A.L.M. (2017) Valoração e sustentabilidade da castanha-do-brasil na Amazônia. Revista de Ciências Agrárias, 60, 77-89. https://doi.org/10.4322/rca.60101

[21] Wadt, L.H.O. and Kainer, K.A. (2009) Domesticação e melhoramento de castanheira. In: Borém, A., Lopes, M.T.G. and Clement, C.R., Eds., Domesticação e melhoramento: Espécies amazônicas, Universidade Federal de Viçosa, Viçosa, Vol. 1, 301-321.

[22] Tonini, H. (2011) Fenologia da castanheira-do-brasil (Bertholletia excelsa Humb. \& Bonpl., Lecythidaceae) no sul do estado de Roraima. Cerne, 17, 123-131.

https://doi.org/10.1590/S0104-77602011000100015 https://doi.org/10.5902/1980509832128

[23] Santos, L.S.M., Lisboa, L.G., Moraes, L.S. and Da, S.C. (2015) Estimativa de rendimento potencial de castanha do Brasil em resposta a oferta pluvial anual na Amazônia. Seminário de Iniciação Científica, Seminário de Pós-Graduação da Embrapa Amazônia Oriental, Belém.

[24] Trazzi, P.A., Higa, A.R., Dieckow, J., Mangrich, A.S. and Higa, R.C.R. (2018) Biocarvão: Realidade e potencial de uso no meio florestal. Ciência Florestal, 28, 875.

[25] Wadt, L.H.O., Kainer, K.A. and Gomes-Silva, D.A.P. (2005) Population Structure and Nut Yield of a Bertholletia excelsa Stand in Southwestern Amazonia. Forest Ecology and Management, 211, 371-384. https://doi.org/10.1016/j.foreco.2005.02.061

[26] Ziproudina, N., Ming, Z. and Hänninen, O.O.P. (2006) Plantar Infrared Thermo- 
graphy Measurements and Low Back Pain Intensity. Journal of Manipulative and Physiological Therapeutic, 29, 219-223. https://doi.org/10.1016/j.jmpt.2006.01.003

[27] Zuidema, P.A. and Boot, R.G.A. (2002) Demography of the Brazil Nut Tree (Bertholletia excelsa) in the Bolivian Amazon: Impact of Seed Extraction on Recruitment and Population Dynamics. Journal of Tropical Ecology, 18, 1-31.

https://doi.org/10.1017/S0266467402002018

[28] Zuidema, P.A. (2003) Demography and Management of the Brazil Nut Tree (Bertholletia excelsa) PROMAB, 111. Riberalta, Bolivia. 